\title{
DNA Polymerase of Reticuloendotheliosis Virus: Inability to Detect Endogenous RNA-Directed DNA Synthesis
}

\author{
RITA M. KIERAS ${ }^{1}$ AND ANTHONY J. FARAS ${ }^{2}$ \\ Department of Microbiology, University of Michigan Medical School, Ann Arbor, Michigan 48104
}

Accepted January 8, 1975

\begin{abstract}
Purified preparations of reticuloendotheliosis virus (REV) appear to lack the endogenous RNase-sensitive DNA polymerase activity present in most, if not all, avian RNA tumor viruses. Although no endogenous RNA-directed DNA polymerase could be detected in REV, we have been able to demonstrate the presence of a virion associated DNA polymerase by employing exogenous synthetic homopolymers as template-primer. A comparison of the REV-associated DNA polymerase activity with the RNA-directed DNA polymerase of Rous sarcoma virus (RSV) reveals similarities in the preference of the enzymes to utilize certain synthetic template primer complexes containing ribopolymers as template. For example, both enzymes prefer poly(rA) oligo(dT) ${ }_{10}$ to poly $(\mathrm{dA}) \cdot \mathrm{oligo}(\mathrm{dT})_{10}$ as template primer. In addition, poly $(\mathrm{rC}) \cdot \mathrm{oligo}(\mathrm{dG})_{10}$ appears to be efficiently utilized by the REV DNA polymerase under conditions whereby a DNA-directed DNA polymerase does not utilize this synthetic homopolymer as template primer. Although the REV 70 S RNA genome is not transcribed by the DNA polymerase contained within virions of $R E V$, it is as good a template - primer for the purified avian oncornavirus RNA-directed DNA polymerase as RSV $70 \mathrm{~S}$ RNA. Furthermore, the virion-associated REV DNA polymerase can transcribe REV $70 \mathrm{~S}$ RNA when oligo(dT) $)_{12-18}$ is present as a source of primer. Therefore, the inability of the REV DNA polymerase to transcribe effectively the REV genome in vitro appears to reflect either some unique property of the REV enzyme or some structural feature of REV $70 \mathrm{~S}$ RNA, such as the lack of certain primer molecules required by the REV DNA polymerase for the initiation of DNA synthesis.
\end{abstract}

\section{INTRODUCTION}

The reticuloendotheliosis viruses (REV) are a newly characterized group of avian RNA viruses that produce reticuloendotheliosis of the viscera and proliferative and infiltrative lymphoid nerve lesions in their avian hosts (Purchase et al., 1973). This group of viruses exhibits several morphological and biochemical features characteristic of the avian leukosis-sarcoma virus (ALSV) complex including morphology, buoyant density, and RNA composition (Zeigel et al., 1966; Baxter-Gabbard et

${ }^{1}$ Present address: Department of Biochemistry, University of Pittsburgh, Pittsburgh, PA 15261.

${ }^{2}$ Author to whom correspondence should be addressed. Present address: Department of Microbiology, University of Minnesota Medical School, Minneapolis, MN 55455. al., 1971; Maldonado and Bose, 1971, 1973; Halpern, 1973; Kang and Temin, 1973). As is the case for the avian RNA tumor viruses, the $\mathrm{REV}$ group contains a segmented, high molecular weight RNA species sedimenting at 60-70 $\mathrm{S}$ (Halpern et al., 1973) and low molecular weight 4 S RNA structurally analogous to tRNA (Staskus, K. and Faras, A., unpublished observations). Although the REV group maintains several features in common with the ALSV complex, considerable serological and genetic differences have been detected between these two groups of avian viruses. For example, REV lacks the group-specific antigen common to all members of the ALSV complex (Theilen, 1966; Maldonado and Bose, 1971). Significant differences have also been detected between the poly- 
peptides of the REV and ALSV groups, and, the REV DNA polymerase appears to be antigenically distinct from the ALSV DNA polymerase (Halpern et al., 1973; Maldonado and Bose, 1973; Mitzutani and Temin, 1973). Furthermore, no biological interaction such as phenotypic complementation or interference could be demonstrated between these virus groups (Halpern et al., 1973). Finally, no detectable nucleic acid sequence homology exists between the genomes of these two groups of avian viruses (Kang and Temin, 1973; Faras, A., unpublished observations) indicating that the REV complex is a separate group of avian RNA viruses distinct from the ALSV complex (Purchase et al., 1973).

The REV group exhibits varying effects on their avian hosts ranging from cytopathic effects on cells in vitro to malignant transformation of cells in vivo (Purchase et al., 1973; Temin and Kassner, 1974; Franklin et al., 1974). In some instances, chronic infection of cells in vitro is also observed (Bose and Levine, 1967). We are currently investigating the mechanism of replication of REV in order to understand better the process of infection by this group of viruses. Although little is known about the mode of replication of these viruses, preliminary evidence suggests that they replicate through a DNA provirus (Temin and Kassner, 1974; Collett et al., 1975) and therefore require reverse transcription for their replication. However, in this communication we report that purified preparations of $\mathrm{REV}$ appear to lack detectable endogenous RNA-directed DNA polymerase activity characteristic of most, if not all, infectious avian RNA tumor viruses. We further report that, although such an endogenous RNA-directed DNA polymerase activity is absent, virions of REV do contain a DNA polymerase activity that exhibits a preference for ribopolymers to deoxyribopolymers as template. The existence of this enzyme was established by employing exogenous synthetic homopolymer complexes as template-primer for the REV DNA polymerase. Data are also presented suggesting that the apparent lack of endogenous REV DNA polymerase activity appears to be a function of the inability of the REV DNA polymerase to utilize available primer molecules associated with the REV genome, since REV $70 \mathrm{~S}$ RNA is as efficient a template -primer as RSV $70 \mathrm{~S}$ RNA for the purified avian oncornavirus RNA-directed DNA polymerase. Furthermore, the REV DNA polymerase can copy the REV genome when oligo $\left(\mathrm{d}^{\prime} \mathrm{T}\right)_{12-18}$ is added to reaction mixtures as a source of primer.

\section{MATERIALS AND METHODS}

Reagents. The sources and preparation of most of the pertinent materials have been described previously (Faras et al., 1972, 1973b, 1974a). Unlabeled deoxynuclcoside triphosphates were obtained from Calbiochem. $\left[{ }^{3} \mathrm{H}\right] \mathrm{TTP}(15-20 \mathrm{Ci} / \mathrm{mmole})$ and $\left[{ }^{3} \mathrm{H}\right] \mathrm{dGTP}(12 \mathrm{Ci} / \mathrm{mmole})$ were from Schwarz BioResearch. Poly $(\mathrm{dA}) \cdot$ oligo$(\mathrm{dT})_{10}, \quad$ poly $(\mathrm{rA}) \cdot \operatorname{oligo}(\mathrm{dT})_{10}, \quad$ poly $(\mathrm{rC})$. oligo $(\mathrm{dG})_{10}, \quad \operatorname{poly}(\mathrm{dC}) \cdot \operatorname{oligo}(\mathrm{dG})_{10}, \quad$ and poly(rA) (6-13 S) were from P-L Biochemicals. Oligo(dT) ${ }_{10-18}$ was from Collaborative Research, Inc., and Takadiastase (Sanzyme) was obtained from Calbiochem.

Cells and virus. Embryonated chick eggs, negative for avian leukosis virus group-specific antigen, were obtained from SPAFAS, Roanoke, Ill. The propagation of the B77 strain of Rous sarcoma virus (RSV) in chick embryo fibroblasts has been previously described (Levinson, 1967). The Cook strain of REV was a kind gift from Dr. G. Purchase. This strain of REV was presumably derived from the original virus isolate of Twiehaus (Strain T) (Theilen, 1966). REV was propagated in chick embryo fibroblasts. RSV and REV were purified by precipitation from tissue culture fluid with ammonium sulfate, followed by sedimentation through $15 \%(\mathrm{w} / \mathrm{v})$ sucrose to a cushion of $40 \%(\mathrm{w} / \mathrm{v})$ potassium tartrate and isopycnic centrifugation in 25$55 \%$ sucrose (Bishop et al., 1970). Purified preparations of REV were found to be free of avian leukosis virus by nucleic acid hybridization (Collett et al., 1975). AMV was a generous gift from Dr. J. Beard of Life Sciences, Inc., St. Petersburg, FL.

Purification of viral RNA. .RNA was extracted from virus with sodium dodecyl 
sulfate (SDS)-phenol at room temperature, and $70 \mathrm{~S}$ RNA was fractionated from the free, low molecular weight RNAs by rate-zonal sedimentation in $15-30 \%$ sucrose in an SW 41 rotor at $40,000 \mathrm{rpm}$ at $4^{\circ}$ for $3 \mathrm{hr}$.

Purification of enzymes. The RNAdirected DNA polymerase of $\mathrm{RSV}$ was partially purified by sequential chromatography on DEAE-cellulose and phosphocellulose as described previously (Faras et al., 1972). Purified AMV RNA-directed DNA polymerase was obtained from Dr. J. Beard through the auspices of the Special Virus Program of the National Cancer Institute. Escherichia coli DNA polymerase I was a gift from Dr. A. DeVries and R. Deleys. The enzyme was purified essentially as described by Heyneker et al. (1973).

The single-strand specific nuclease, $S_{1}$ was purified from Takadiastase powder by DEAE-cellulose chromatography essentially as described by Sutton (1971). Standard reaction mixtures contained 0.03 $M$ Sodium acetate buffer, $\mathrm{pH} 4.5,1.8 \times$ $10^{-3} M \mathrm{ZnCl}_{2}, 0.3 M \mathrm{NaCl}, 10 \mu \mathrm{g} / \mathrm{ml}$ of denatured calf thymus DNA and approximately 200 units/ml of $S_{1}$ nuclease (Leong et al., 1972). Reactions were incubated for $2 \mathrm{hr}$ at $50^{\circ}$. Under these conditions, more than $98 \%$ of single-stranded DNA and less than $1.0 \%$ of double-stranded DNA was hydrolyzed.

Synthesis and purification of RSV-and $R E V$-specific complementary $D N A$. The enzymatic synthesis of DNA complementary to the RNA genomes (cDNA) of RSV and $\mathrm{REV}$ was performed in presence of 100 $\mu \mathrm{g} / \mathrm{ml}$ of actinomycin $\mathrm{D}$ and $20 \mu \mathrm{g} / \mathrm{ml}$ of oligo $(\mathrm{dT})_{12-18}$ under conditions described in Table 1 except that incubation was for 6 hr at $37^{\circ}$. The reaction mixture was then adjusted to $10 \mathrm{~m} M$ EDTA, $0.5 \%$ SDS, and $500 \mu \mathrm{g} / \mathrm{ml}$ of Pronase and incubated for 30 $\min$ at $37^{\circ}$. The nucleic acids were extracted with STE $(0.1 M \mathrm{NaCl}, 0.02 M$ Tris- $\mathrm{HCl}$, pH 794, $0.01 M$ EDTA-saturated phenol at room temperature and the viral RNA removed from the cDNA preparations by hydrolysis with $0.6 \mathrm{M}$ $\mathrm{NaOH}$ for $5 \mathrm{hr}$ at $37^{\circ}$. Conditions for hybridization are in the footnote to Table 3.

\section{RESULTS}

Lack of Endogenous RNA-Directed DNA Polymerase Activity in Virions of $R E V$

Purified preparations of REV were tested for the presence of endogenous RNA-directed DNA polymerase activity under reaction conditions that elicit maximum endogenous DNA polymerase activity from all other avian RNA tumor viruses tested in this laboratory to date. A comparison of the ability of detergent-disrupted RSV and REV to synthesize DNA under various conditions is presented in Table 1 and Fig. 1. Whereas considerable RNase-sensitive DNA-polymerase activity is observed with RSV, little, if any, endogenous RNase-sensitive DNA polymerase activity can be detected with equivalent concentrations of detergent-disrupted REV (Table 1). Varying the $\mathrm{pH}$, divalent cation concentration, or replacement of $\mathrm{MgCl}_{2}$ with $\mathrm{MnCl}_{2}$ did not stimulate an REV endogenous DNA polymerase activity (data not shown). The RSV DNA polymerase activity exhibits a sharp dependence upon detergent, having an optimum activity at approximately $0.05 \%$ NP-40 (Fig. 1A). However, varying the concentration of detergent from $0.001-$ $1.0 \%$ did not stimulate the endogenous synthesis of DNA from virions of REV (Fig. 1A). Virions of REV did not inhibit the endogenous RNA-directed DNA polymerase activity of RSV when both viruses were included in the reaction mixture suggesting that the lack of endogenous RNA-directed DNA synthesis with REV was probably not due to some inhibitor present within the virion particle or the result of nuclease(s) degrading the REV RNA template (Table 1).

\section{Detection of REV DNA Polymerase Activ- ity with Synthetic Homopolymers}

Although no measurable endogenous DNA polymerase activity was observed in preparations of detergent-disrupted REV, a DNA polymerase activity could be detected upon the addition of various exogenous template-primers to the reaction mixtures (Table 1). A slight, but measurable stimulation of this REV DNA polymerase activity could be observed using calf 
TABLE 1

Template Specifictites or REV, RSV and $E$. coli DNA Polymerases ${ }^{a}$

\begin{tabular}{|c|c|c|c|}
\hline \multirow{2}{*}{$\begin{array}{l}\text { Additions to the } \\
\text { endogenous reaction }\end{array}$} & \multicolumn{3}{|c|}{ Relative incorporation (pmoles) } \\
\hline & RSV & REV & E. coli \\
\hline None & 3.20 & $<0.03$ & - \\
\hline RNase $^{b}$ & 0.15 & $<0.03$ & - \\
\hline Calf thymus $\mathrm{DNA}^{c}$ & 3.85 & 0.15 & 21.1 \\
\hline Poly $(\mathrm{rA}) \cdot$ oligo $(\mathrm{dT})_{10} \mathrm{c}$ & $17.50(14.34)^{d}$ & $9.08(4.80)$ & $0.28(0.05)$ \\
\hline Poly $(d A) \cdot$ oligo $(d T)_{10}$ & $3.12(2.32)$ & $0.24(0.19)$ & $0.26(0.36)$ \\
\hline Poly $(\mathrm{rC}) \cdot \operatorname{oligo}(\mathrm{dG})_{10}$ & 10.36 & 5.83 & 0.04 \\
\hline $\operatorname{Poly}(\mathrm{dC}) \cdot \operatorname{oligo}(\mathrm{dG})_{10}$ & 48.69 & 29.51 & 6.47 \\
\hline RSV $70 S \mathrm{KNA}^{\mathrm{c}}$ & 6.20 & $<0.03$ & - \\
\hline $\mathrm{REV}^{e}$ & 2.97 & - & - \\
\hline
\end{tabular}

a Standard reaction mixtures contained $100 \mu \mathrm{g} / \mathrm{ml}$ of viral protein, $0.1 \mathrm{MTris}-\mathrm{HCl}$ (pH 8.1), $0.01 \mathrm{M} \mathrm{MgCl}_{2}$, $2 \%$ (v/v) $\beta$-mercaptoethanol, $0.1 \%$ NP-40, three unlabeled deoxynucleoside triphosphates $\left(5 \times 10^{-5} M\right)$, and one ${ }^{9} \mathrm{H}$-labeled deoxynucleoside triphosphate (TTP or dGTP, $5 \times 10^{-6} \mathrm{M}$ ). The ${ }^{3} \mathrm{H}$-labeled precursors were $\left[{ }^{3} \mathrm{H}\right]$ TTP $(10,000 \mathrm{cpm} / \mathrm{pmole})$ for the endogenous, DNA-stimulated, and poly $(\mathrm{rA}) \cdot \mathrm{oligo}(\mathrm{dT})_{10^{-}}$or poly $(\mathrm{dA}) \cdot$ oligo $(\mathrm{dT})_{10^{-}}$-stimulated reactions and $\left[{ }^{3} \mathrm{H}\right] \mathrm{dGTP}(8,000 \mathrm{cpm} / \mathrm{pmole})$ for the poly $(\mathrm{rC}) \cdot \mathrm{oligo}(\mathrm{dG})_{10^{-}}$or poly $(\mathrm{dC}) \cdot$ oligo $(\mathrm{dG})_{10}$-stimulated reactions. Reaction mixtures containing $E$. coli DNA polymerase I were identical to those described for RSV and REV except that virus was replaced with $0.2 \mathrm{units} / \mathrm{ml}$ of the $E$. coll enzyme. All enzymatic reactions were incubated for $2 \mathrm{hr}$ at $37^{\circ}$. Incorporation of radiolabeled precursors into acid-insoluble material was assayed as described by Garapin et al. (1970).

${ }^{\circ}$ RNase-treatment $(500 \mu \mathrm{g} / \mathrm{ml})$ was performed for $15 \mathrm{~min}$ at $37^{\circ}$ prior to the addition of deoxynucleoside triphosphates to the reaction mixtures.

c The final concentration of all exogenously added templates in the reaction mixture was $20 \mu \mathrm{g} / \mathrm{ml}$.

${ }^{d}$ Numbers in parentheses indicate [ ${ }^{3} \mathrm{H}$ ] $\mathrm{TMP}$ incorporated under standard reaction conditions described in footnote $a$ except that $60 \mathrm{~m} M \mathrm{KCl}$ was included in the reaction mixtures. Under these conditions DNA-directed DNA polymerases exhibit a marked preference for poly $(\mathrm{dA}) \cdot \mathrm{oligo}(\mathrm{dT})_{10}$ over poly $(\mathrm{rA}) \cdot \mathrm{oligo}(\mathrm{dT})_{10}$ as template primer (Baltimore and Smoler, 1971; Goodman and Spiegelman, 1971).

- An equal concentration of purified REV was added to an RSV-containing reaction mixture. Reaction conditions were similar to those described in footnote a except that the NP- 40 concentration was $0.2 \%$. The reactions were incubated for $2 \mathrm{hr}$ at $37^{\circ}$.
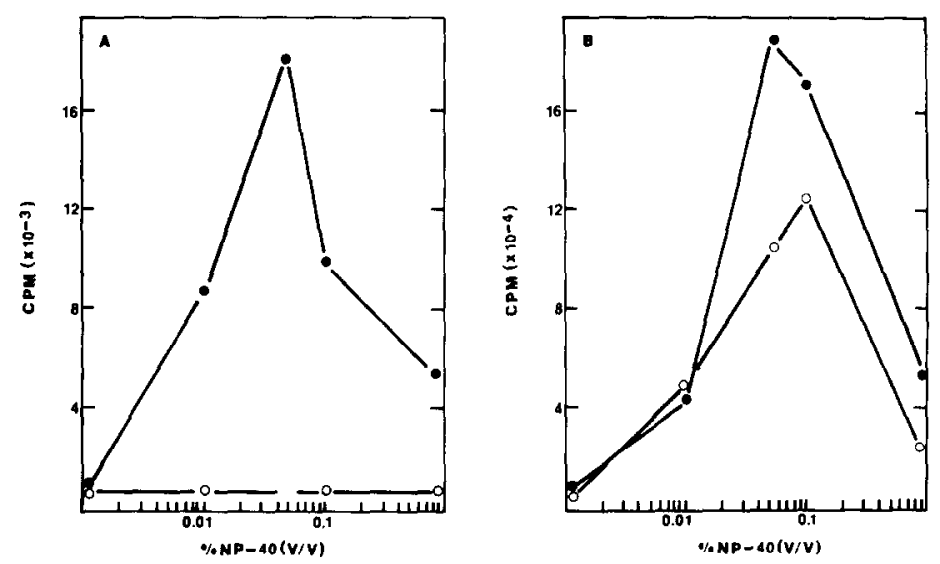

FIG. 1. Effect of detergent concentration on REV-associated DNA polymerase activity. (A), Samples of purified RSV and REV ( $100 \mu \mathrm{g} / \mathrm{ml}$ of viral protein) were incubated in standard reaction mixtures as described in Table 1. Reaction mixtures contained the indicated amounts of NP-40 and were incubated for $2 \mathrm{hrs}$ at $37^{\circ}$. (B), Conditions were as in (A) except that $20 \mu \mathrm{g} / \mathrm{ml}$ of poly(rA) $\cdot$ oligo(dT) ${ }_{10}$ was added to the reaction mixtures as template-primer. $\mathrm{RSV}$; $\mathrm{O}, \mathrm{REV}$. 
thymus DNA as template-primer. However, a more dramatic stimulation of DNA polymerase activity is observed when certain synthetic homopolymers are added to reaction mixtures containing REV (Table 1). These synthetic homopolymers can be used to differentiate between RNA-directed and DNA-directed DNA polymerase activities (Baltimore and Smoler, 1971; Goodman and Spiegelman, 1971; Wells et al., 1972; Robert et al., 1972; Scolnick and Parks, 1973; Verma and Baltimore, 1973). Both the RSV RNA-directed DNA polymerase and the DNA polymerase activity associated with virions of REV exhibit a marked preference for certain ribohomopolymers over the homologous deoxyribopolymers as template (Table 1). For example, both enzymes prefer poly $(\mathrm{rA}) \cdot \operatorname{oligo}(\mathrm{dT})_{10}$ to poly $(\mathrm{dA}) \cdot$ oligo $(\mathrm{dT})_{10}$ as template. primer, whereas no demonstrable preference for poly $(\mathrm{rA}) \cdot$ oligo $(\mathrm{dT})_{10}$ is observed with the DNA-directed DNA polymerase I from $E$ coli. In fact, under certain conditions this latter enzyme shows preference for the deoxyribohomopolymer template. primer complex poly $(\mathrm{dA}) \cdot \operatorname{oligo}(\mathrm{dT})_{10}$. A similar preference has been demonstrated for several recently isolated eukaryotic DNA-directed DNA polymerases (Chang and Bollum, 1972; Sedwick et al., 1972; Smith and Gallo, 1972). Both the RSV and REV DNA polymerases prefer poly $(\mathrm{rA}) \cdot \operatorname{oligo}(\mathrm{dT})_{10}$ to calf thymus DNA as template, whereas the $E$. coli DNA polymerase exhibits a much poorer response to poly(rA)-oligo(dT) 10 than to calf thymus DNA as template.

We also tested the ability of the REV DNA polymerase to effectively utilize the synthetic homopolymer poly $(\mathrm{rC})$-oligo(dG) 10 , a template-primer that is efficiently copied by only RNA-directed DNA polymerases of RNA tumor viruses (Temin and Baltimore, 1972; Baltimore et al., 1973) (Table 1). Both the RSV and REV enzymes can utilize poly $(\mathrm{rC})$. oligo(dG) $)_{10}$ whereas the $E$. coli DNAdirected DNA polymerase shows little, if any, incorporation of labeled precursor with this template-primer complex. In all cases, poly $(\mathrm{dC}) \cdot \operatorname{oligo}(\mathrm{dG})_{10}$ is a more efficient template-primer than poly $(\mathrm{rC})$. oligo $(\mathrm{dG})_{10}$ for enzymatic activity. However, the ability of a DNA polymerase to utilize poly(rC) -oligo $(\mathrm{dG})_{10}$ as template-primer is suggestive of a reverse transcriptase activity (Temin and Baltimore, 1972; Baltimore et al., 1973).

The DNA polymerase activity detected in virions of REV requires the presence of a detergent for activity, indicating that the enzyme is probably contained within the virus particle (Figure 1B). The optimum activity of the REV DNA polymerase is in the range of the detergent concentration required for maximum activity of $\mathrm{RSV}$ (Figure 1B). We conclude from these results that virions of REV contain a DNApolymerase activity that appears similar to the RSV RNA-directed DNA polymerase in its response to synthetic template - primers.

\section{Stimulation of the Endogenous REV DNA Polymerase Reaction by Addition of Exogenous Primer}

The RSV RNA-directed DNA polymerase requires the $3^{\prime}$ terminus of a primer molecule for the initiation of DNA synthesis in vitro (Taylor et al., 1973; Faras et al., 1973; Dahlberg et al., 1974). We have previously demonstrated that the addition of oligo(dT) ${ }_{12-18}$ to detergent-disrupted virions of RSV stimulates the endogenous synthesis of DNA two- to threefold (Taylor et al., 1972 and Table 2). This stimulation presumably occurs as a result of the association of oligo $(\mathrm{dT})_{12-18}$ with the poly(A) region of the viral genome, thereby producing additional primers for the initiation of DNA synthesis by the RNA-directed DNA polymerase. To determine whether the addition of an exogenous primer would similarly stimulate the endogenous REV DNA polymerase to copy REV-RNA we investigated the effect of adding oligo $(\mathrm{dT})_{12-18}$ to reactions containing detergent-disrupted REV. The results presented in Table 2 indicate that the REV endogenous reaction is stimulated considerably by the addition of oligo(dT) $)_{12-18}$ to the reaction mixture, suggesting that the REV DNA polymerase is capable of transcribing the REV genome if an appropriate primer is available for the initiation of DNA synthesis. Under identi- 
cal reaction conditions, oligo $(\mathrm{dT})_{12-18}$ by itself does not act as template for the purified RSV DNA polymerase nor will it stimulate the response of the RSV enzyme to exogenously added calf thymus DNA (Taylor et al., 1973). The oligo $(\mathrm{dT})_{12-18^{-}}$ stimulated enzymatic reaction can be completely eliminated by pretreatment of the virus with RNase indicating that the bulk of the DNA product synthesized in response to oligo $(\mathrm{dT})_{12-18}$ is transcribed from RNA (Table 2).

Finally, we have employed nucleic acid hybridization techniques to demonstrate that the DNA product made in the presence of oligo(dT) ${ }_{12-18}$ is REV-specific. The data presented in Table 3 indicate that the bulk of the cDNA, synthesized in an

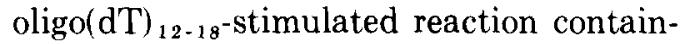
ing REV, hybridizes specifically to REV 70 S RNA. Similarly, cDNA synthesized by disrupted virions of RSV in the presence of oligo(dT) ${ }_{12-18}$ hybridizes to the same extent to RSV $70 \mathrm{~S}$ RNA. A small amount of cross-hybridization can also be detected between RSV and REV. This appears not to be a result of contamination of our REV preparations with avian leukosis virus, because our stocks of REV are free of detectable avian sarcoma or leukosis virus-specific nucleic acid sequences (Kang and Temin, 1973; Collett et al., 1975). Furthermore, REV-and RSV-cDNA hybridize to poly(A) to the same extent that they cross-hybrid-

TABLE 2

Effect of Exogenous Primer on Endogenous REV DNA-Polymerase Activity

\begin{tabular}{lcc}
\hline \multicolumn{1}{c}{ Additions } & \multicolumn{2}{c}{$\begin{array}{c}\text { Relative incorporation } \\
\text { (pmoles) }^{a}\end{array}$} \\
\cline { 2 - 3 } & $\mathrm{RSV}$ & $\mathrm{REV}$ \\
\hline Control & 1.00 & $<0.03$ \\
RNase & 0.10 & $<0.03$ \\
Oligo(dT) ${ }_{12-18}$ & 1.70 & 0.87 \\
Oligo(dT) ${ }_{12-18}$ plus RNase & 0.19 & 0.11 \\
\hline
\end{tabular}

${ }^{a}$ Conditions for enzymatic synthesis of DNA were as described in Table 1 . The incorporation of $\left[{ }^{3} \mathrm{H}\right] \mathrm{TMP}$ into acid-insoluble material is expressed relative to the incorporation observed with RSV in the absence of added primer. The synthetic primer oligo(dT) ${ }_{12-18}$ was used at a concentration of $20 \mu \mathrm{g} / \mathrm{ml}$. RNase pretreatment was as described in Table 1 .
TABLE 3

SPECIFICITY OF REV CDNA SYNTHESIzEd IN THE Presence of Oligo(dT) 12 18

\begin{tabular}{clc}
\hline cDNA $^{a}$ & \multicolumn{1}{c}{ RNA $^{b}$} & \% DNA hybridized \\
\hline RSV & $70 \mathrm{~S} \mathrm{RSV}$ & 75.2 \\
RSV & $70 \mathrm{~S} \mathrm{REV}$ & 10.6 \\
$\mathrm{RSV}$ & Poly(A) & 8.5 \\
$\mathrm{REV}$ & $70 \mathrm{~S} \mathrm{RSV}$ & 18.5 \\
$\mathrm{REV}$ & $70 \mathrm{~S} \mathrm{REV}$ & 77.9 \\
$\mathrm{REV}$ & Poly(A) & 18.6 \\
\hline
\end{tabular}

${ }^{a}$ cDNA was synthesized essentially under conditions described in Table 2. The presence of $100 \mu \mathrm{g} / \mathrm{ml}$ of actinomycin $\mathrm{D}$ was included in the reaction mixtures to promote a more uniform transcription of the template RNA into DNA (Garapin et al., 1973). The synthetic primer oligo $\left(d^{T}\right)_{12-1 a}$ was included at a concentration of $20 \mu \mathrm{g} / \mathrm{ml}$. cDNA $(8,900 \mathrm{cpm} / 0.001$ $\mu \mathrm{g})$ was purified from reaction mixtures as described in Materials and Methods.

b70 S RSV and REV-RNAs were extracted from purified virus as described in Materials and Methods.

c Approximately 2,500 cpm of cDNA was hybridized to a vast excess of RNA $(1,000: 1)$ in $0.3 \mathrm{M}$ $\mathrm{NaCl}-0.001 M$ EDTA-0.02 $M$ Tris- $\mathrm{HCl}$, pH 7.4, at $68^{\circ}$ to a $C_{\mathrm{r}} t$ of 2.30 . The extent of hybridization was determined by measuring duplex DNA - RNA hybrids with $S_{1}$ nuclease (Leong et al., 1972).

ize to RSV and REV 70 S RNA, respectively, suggesting that the cross-hybridization observed is probably due to some poly $(\mathrm{dT})$ sequences synthesized during the course of the enzymatic reaction. Employing more direct methods we have previously reported that the DNA product synthesized in the presence of oligo$(d T)_{12-18}$ does indeed contain some poly$(\mathrm{dT})_{n}$ sequences which are presumably transcribed from the poly(A)-containing end of the RSV genome (Taylor et al., 1973).

\section{Ability of REV $70 S R N A$ to Function as Template.Primer for the Avian RNA Tumor Virus DNA Polymerase}

The above results indicate that exogenously added primer is capable of stimulating the endogenous REV DNA polymerase to transcribe the REV RNA-genome into DNA. Since no endogenous REV DNA polymerase activity is observed in the absence of exogenous primer, it is conceivable that the native REV 70 S RNA complex may not be capable of serving as functional template primer for the RNA- 
directed synthesis of DNA. However, as indicated in Table 4, REV $70 \mathrm{~S}$ RNA is as efficient a template primer as avian leukosis or sarcoma virus $70 \mathrm{~S}$ RNA for the purified RNA-directed DNA polymerase of either RSV or AMV. Therefore, it appears that REV $70 \mathrm{~S}$ RNA is a suitable template primer for the avian oncornavirus DNA polymerase. Furthermore, RSV $70 \mathrm{~S}$ RNA does not stimulate the virionassociated DNA polymerase of REV to synthesize DNA when added to reaction mixtures containing detergent-disrupted virus (Table 1). Under similar reaction conditions exogenous RSV 70 S RNA does stimulate the RSV-associated DNA polymerase. These preliminary results suggest that the REV enzyme may be unable to utilize avian oncornavirus $70 \mathrm{~S}$ RNA as a template-primer. However, since either REV-associated nucleases and/or a limited accessiblity of exogenous $70 \mathrm{~S}$ RNA to the REV-associated DNA polymerase could conceivably account for these observations, further studies employing purified REV DNA-polymerase and RSV 70 S RNA will be required.

\section{DISCUSSION}

We have been unable thus far to detect, in purified preparations of REV, an endogenous DNA polymerase reaction in which

TABLE 4

Template Activity of REV 70 S RNA

\begin{tabular}{llc}
\hline RNA & Enzyme & $\begin{array}{c}{ }^{3} \text { H JTMP } \\
\text { Incorporated } \\
\text { (cpm) }{ }^{a}\end{array}$ \\
\hline RSV & RSV & 4219 \\
RSV & AMV & 4405 \\
RAV-2 & RSV & 4092 \\
RAV-2 & AMV & 4923 \\
REV & RSV & 4209 \\
REV & AMV & 4047 \\
AMV & RSV & $\mathbf{4 4 6 2}$ \\
AMV & AMV & 5539 \\
\hline
\end{tabular}

a Enzymatic conditions were essentially as described in Table 1 except that both detergent and virus were omitted from the reaction mixtures. Approximately 0.4 units $/ \mathrm{ml}$ of purified AMV or RSV DNA-polymerase and $2 \mu \mathrm{g} / \mathrm{ml}$ of template RNA were incubated under these reaction conditions for $1 \mathrm{hr}$ at $37^{\circ}$. the $70 \mathrm{~S}$ virion $\mathrm{RNA}$ acts as a template for the synthesis of DNA. However, by employing exogenous synthetic homopolymers that are routinely utilized for differentiating RNA-directed DNA polymerase activity from DNA-directed DNA polymerase activity, we have detected a virionassociated DNA polymerase that prefers ribopolymers to deoxyribopolymers as template. We have also demonstrated that the REV DNA polymerase is capable of copying REV-RNA if the exogenous primer, oligo(dT) ${ }_{12-18}$, is added to the reaction mixture. Furthermore, both the RSV and AMV RNA-directed DNA polymerases can efficiently transcribe purified REV $70 \mathrm{~S}$ RNA indicating that the REV genome is an efficient template primer complex for the avian oncornavirus RNA-directed DNA polymerase. It therefore appears either that the REV $70 \mathrm{~S}$ RNA genome lacks a specific primer molecule required by the REV DNA polymerase and not by the RSV DNA polymerase for the initiation of DNA synthesis, or that some property of the REV DNA polymerase renders it incapable of transcribing REV-RNA as efficiently as the avian RNA tumor virus DNA-polymerase. We are currently attempting to differentiate between these possibilities. Previous studies have demonstrated that the RSV DNA polymerase utilizes a specific species of $4 \mathrm{~S}$ RNA as primer for the initiation of DNA synthesis on the RSV 70 S RNA genome (Faras et al., 1973b; Dahlberg et al., 1974; Faras et al., 1974b). Preliminary studies from our laboratory indicate that the REV genome contains $4 \mathrm{~S}$ RNA but further studies will be required to determine if any of these $4 \mathrm{~S}$ molecules are capable of functioning as primers in RNAdirected DNA synthesis. In addition, studies are currently in progress to attempt to determine similarities and/or differences between the purified REV and RSV DNA polymerases.

Our inability to detect an endogenous RNA-directed DNA-polymerase activity in purified preparations of REV is in agreement with a recent communication by Kang and Temin who failed to detect an endogenous RNase-sensitive DNA polymerase activity associated with another 
member of the REV group (Trager duck spleen necrosis virus) (Kang and Temin, 1973). However, our results are in contrast to those of Peterson et al. (1972) who previously reported that an endogenous RNasesensitive DNA polymerase activity could be detected in virions of REV. Although other explanations cannot be excluded at this time, we feel that the most likely explanation of this discrepancy between their results and ours is that the RNasesensitive DNA polymerase activity previously reported by these authors was a result of a contaminating avian leukosis virus acquired during propagation of REV.

Verma et al. (1974) recently characterized a DNA polymerase associated with virions of hamster leukemia virus ( $\mathrm{HaLV}$ ) that was incapable of transcribing the HaLV RNA-genome in an endogenous reaction. However, the HaLV enzyme differs from the REV DNA polymerase in that it could neither utilize poly $(\mathrm{rA}) \cdot \operatorname{oligo}(\mathrm{dT})_{10}$ efficiently nor transcribe HaLV-RNA when exogenous oligo $\left(d^{\prime} T\right)_{12-18}$ primer was added to the reaction mixtures.

The lack of an endogenous RNA-directed DNA polymerase activity does not apparently prohibit REV from replicating through a DNA provirus intermediate similar to the avian RNA tumor viruses. We and others have demonstrated that virusspecific DNA synthesis is indeed required for replication of these viruses in chick embryo fibroblasts (Temin and Kassner, 1974; Collett et al., 1975). Furthermore, the presence of REV-specific DNA sequences can be directly detected in cells after infection by hybridization techniques (Collett et al., 1975; Kang and Temin, 1974). Whether a host cell function is required to facilitate transcription of the REV genome subsequent to infection of cells with REV has yet to be determined.

\section{ACKNOWLEDGMENTS}

We thank C. Collins and W. Folk for editorial assistance and N. Dibble and C. Fox for excellent technical assistance. This investigation was supported by Public Health Service Research Grant No. CA 14790-02 from The National Cancer Institute and Grant No. DRG-1268 from the Damon Runyon Memorial Fund for Cancer Research.

\section{REFERENCES}

Baltimore, D., and Smoler, D. (1971). Primer requirement and template specificity of the DNA polymerase of RNA tumor viruses. Proc. Nat. Acad. Sci. USA 68, 1507-1511.

Baltimore, D., McCaffrey, R., and Smoler, D. F. Properties of reverse transcriptases. In "Virus Research" (C. F. Fox and W. S. Robinson, eds.), pp. 51-59. Academic Press, New York.

Baxter-Gabbard, K. L., Campbell, W. F., Padgett, F., Rattano-Fenton, A., and Levine, A. (1971). Avian reticuloendotheliosis (strain T). II. Biochemical and biophysical properties. Avian Dis. 15, 850-862.

Bishop, J. M., Levinson, W. E., Quintrell, N., Sullivan, D., Fanshier, L., and Jackson, J. (1970). The low molecular weight RNAs of Rous sarcoma virus. I. The $4 \mathrm{~S}$ RNA. Virology 42, 182-195.

Bose, H. R., and Levine, A. S. (1967). Replication of the reticuloendotheliosis virus (strain $\mathrm{T}$ ) in chicken embryo cell culture. J. Virol. 1, 1117-1121.

Chang, L., and Bollum, F. (1972). Low molecular weight deoxyribonucleic acid polymerase from rabbit bone marrow. Biochemistry 11, 1264-1272.

Collett, M. S., Kieras, R. M., and Faras, A. T. (1975). Studies on the replication of reticuloendotheliosis virus: Detection of viral-specific DNA sequences in infected cells. Virology 65, 436-445.

Dahlberg, J. E., Sawyer, R. C., Taylor, J. M., Faras, A. J., Levinson, W. E., Goodman, H. M., and Bishop, J. M. (1974). Transcription of DNA from the 70 S RNA of Rous sarcoma virus. I. Identification of a specific $4 \mathrm{~S}$ RNA which serves as primer. $J$. Virol. 13, 1126-1133.

Faras, A. J., Taylor, J. M., McDonnell, J. P., Levinson, W. E., and Bishop, J. M. (1972). Purification and characterization of the deoxyribonucleic acid polymerase associated with Rous sarcoma virus. Biochemistry 11, 2334-2342.

Faras, A. J., Garapin, A. C., Levinson, W. E., Bishop, J. M., and Goodman, H. M. (1973). Characterization of the low molecular-weight RNAs associated with the $70 \mathrm{~S}$ RNA of Rous sarcoma virus. J. Virol. $12,334-342$.

Faras, A. J., Taylor, J. M., Levinson, W. E., Goodman, H. M., and Bishop, J. M. (1973), RNAdirected DNA polymerase of Rous sarcoma virus: Initiation of synthesis with $70 \mathrm{~S}$ viral RNA as template. J. Mol. Biol. 79, 163-183.

Faras, A. J., Levinson, W. E., Bishop, J. M., and Goodman, H. M. (1974). Identification of a tRNA nucleotidyltransferase and its substrates in virions of avian RNA tumor viruses. Virology 58, 126-135.

Faras, A. J., Dahlberg, J. M., Sawyer, R. C., Harada, F., Taylor, J. M., Levinson, W. E., Bishop, J. M., and Goonman, H. M. (1974). Transcription of DNA from the $70 \mathrm{~S}$ RNA of Rous sarcoma virus. II. Structure of a 4 S RNA primer. $J$. 
Virol. 13, 1134-1142.

FARAS, A. J., and DibBle, N. A. (1975). RNA-directed DNA synthesis by the DNA polymerase of Rous sarcoma virus: Structural and functional identification of $4 \mathrm{~S}$ primer RNA in uninfected cells. Proc. Nat. Acad. Sci. USA, in press.

Franklin, R. B., Maldonado, R. L., and Bose, H. R. (1974). Isolation and characterization of a reticulendotheliosis virus transformed cell line (Abstract). Annu. Meeting Soc. Microbiol., p. 232.

Gahapin, A. C., McDonnell, J., Levinson, W., Quintrell, N., Fanshier, L., and Bishop, J. (1970). Deoxyribonucleic acid polymerase associated with Rous sarcoma virus and avian myeloblastosis virus: Properties of the enzyme and its product. J. Virol. 6, 589-598.

Garapin, A. C., Varmus, H. E., Faras, A. J., Levinson, W. E., and Bishop, J. M. (1973). RNAdirected DNA synthesis by virions of Rous sarcoma virus: Further characterization of the templates and the extent of their transcription. Virology 52, 265-273.

Goodman, N., and Spiegelman, S. (1971). Distinguishing reverse transcriptase of an RNA tumor virus from other known DNA polymerases. Proc. Nat. Acad. Sci. USA 68, 2203-2206.

Halpern, M. S., Wade, E., Rucker, E., BaxterGabBard, R. L., LeVINe, A., and Fris, R. R. (1973). A study of the relationship of reticuloendotheliosis virus to the avian leukosis-sarcoma complex of viruses. Virology 53, 287-299.

Heyneker, H. L., Ellens, D. J., TJeerde, R. H., Glickman, B. W., van Dorp, B., and Pouwels, P. H. (1973). A mutant of $E$. coli K12 deficient in the $5^{\prime} \rightarrow$ $3^{\prime}$ exonucleolytic activity of DNA polymerase $\mathrm{I}$. Mol. Gen. Genet. 124, 83-96.

KANG, C. Y., and Temin, H. M. (1973). Lack of sequence homology among RNAs of avian leukosissarcoma viruses, reticuloendotheliosis viruses, and chicken endogenous RNA-directed DNA polymerase activity. J. Virol. 12, 1314-1324.

KanG, C. Y., and Temin, H. M. (1974). Reticuloendotheliosis virus nucleic acid sequences in cellular DNA. J. Virol. 14, 1179-1188.

Katz, L., and Penman, S. (1967). The influence of co-precipitants on the solvent-denaturation of double-stranded RNA. Biochem. Biophys. Res. Commun. 27, 456-461.

Leong, J., Garapin, A-C., Jackson, H., Fanshier, L., Levinson, W., and Bishop, J. M. (1972). Virusspecific ribonucleic acid in cells producing Rous sarcoma virus: detection and characterization. $J$. Virol. 9, 891-902.

Levinson, W. (1967). Fragmentation of the nucleus in Rous sarcoma virus-infected chick embryo cells. Virology 32, 74-83.

Maldonado, R. L., and Bose, H. R. (1971). Separation of reticuloendotheliosis virus from avian RNA tumor viruses. J. Virol. 8, 813-815.
Maldonado, R. L., and Bose, H. R. (1973). Relationship of reticuloendotheliosis virus to the avian tumor viruses: Nucleic acid and polypeptide composition. J. Virol. 11, 741-747.

Mizutani, S., and Temin, H. (1973). Lack of serological relationship among DNA polymerases of avian leukosis-sarcoma viruses, reticulaendotheliosis viruses, and chicken cells. J. Virol. 12, 440-448.

Peterson, D. A., Baxter-Gabiard, K. L., and Levine, A. S. (1972). Avian reticuloendotheliosis virus (Strain T). V. DNA polymerase. Virology 47, 251-254.

Purchase, G. H., Ludford, C., Nazerian, K., and Cox, H. W. (1973). A new group of oncogenic viruses: Reticuloendotheliosis, chick syncytial, duck infectious anemia, and spleen necrosis viruses. J. Nat. Cancer Inst. 51, 489-497.

Robert, M., Smith, R., Gallo, R., Sarin, P., and ABReLL, J. (1972). Viral and cellular DNA polymerases: Comparison of activities with synthetic and natural RNA templates. Sciences 176, 798-800.

Scolnick, E. M., and PARKs, W. P. (1973). Identification of viral reverse transcriptase. In "Methods in Enzymology" (L. Grossman, and K. Moldave, eds.), Vol. 29, pp. 130-143. Academic Press, New York.

Sedwick, W., Wank, T., and Korn, D. (1972). Purification and properties of nuclear and cytoplasmic deoxyribonucleic acid polymerases from human $\mathrm{KB}$ cells. J. Biol. Chem. 247, 5026-5033.

Smith, R. G., and Gallo, R. C. (1972). DNA-dependent DNA polymerases I and II from normal humanblood lymphocytes. Proc. Nat. Acad. Sci. USA 69, 2879-2884.

Sutton, W. D. (1971). A crude nuclease preparation suitable for use in DNA reassociation experiments. Biochim. Biophys. Acta 240, 522-531.

Taylor, J. M., Faras, A. J., Varmus, H. E., Levinson, W. E., and Bishop, J. M. (1973). Transcription of ribonucleic acid by the ribonucleic acid-directed deoxyribonucleic acid polymerase of Rous sarcoma virus and deoxyribonucleic acid polymerase $I$ of Escherichia coli. Biochemistry 12, 460-467.

Temin, H., and Battimore, D. (1972). RNA-directed DNA synthesis and RNA tumor viruses. In "Advances in Virus Research" (K. M. Smith and M. A. Lauffer, eds.), Vol. 17, pp. 129-186. Academic Press, New York.

Temin, H. M., and Kassner, V. R. (1974). Replication of reticuloendotheliosis viruses in cell culture: Acute infection. J. Virol. 13, 291-297.

Theilen, G. H., Zeigel, R. F., and Twiehaus, M. J. (1966). Biological studies with the RE virus (strain $T$ ) that induces reticuloendotheliosis in turkeys, chickens and Japanese quail. J. Nat. Cancer Inst. 37, 731-743.

Verma, I. M., and Baltimore, D. (1973). Purification of the RNA-directed DNA polymerase from avian myeloblastosis virus and its assay with polynucleo- 
tide templates. In "Methods in Enzymology" (L. Grossman, and K. Moldave, eds.), Vol. 29, pp. 125-150. Academic Press, New York.

Verma, I. M., Meuth, N. L., Fan, H., and Baltimore, D. (1974). Hanster leukemia virus: Lack of endogenous DNA synthesis and unique structure of its DNA polymerase. $J$. Virol. 13, 1075-1082.

Wells, R. D., Flugel, R. M., LaRson, J. E., Schendel, P. K., and Sweet, R. W. (1972). Composition of some reactions catalyzed by deoxyribonucleic acid polymerase from avian myeloblastosis virus, Escherichia coli, and Micrococcus luteus. Biochemistry. 11, 621-628.

Zeigel, R. F., Theilen, G. H., and Twiehaus, M. J. (1966). Electron microscopic observations on RE virus (strain E) that induces reticuloendotheliosis in turkeys, chickens, and Japanese quail. J. Nat. Cancer Inst. 37, 709-729. 